\title{
GIS-Based Social Cost-Benefit Analysis on Integrated Urban Water Management in China: A Case Study of Sponge City in Harbin
}

\author{
Xuezhou Fan ${ }^{1, *(1)}$ and Toru Matsumoto ${ }^{2}$ \\ 1 Graduate School of Environmental Engineering, University of KITAKYUSHU, Kitakyushu, \\ Fukuoka 802-8577, Japan \\ 2 Faculty of Environmental Engineering, University of KITAKYUSHU, Kitakyushu, Fukuoka 808-0135, Japan; \\ matsumoto-t@kitakyu-u.ac.jp \\ * Correspondence: fanxuezhou@163.com; Tel.: +81-70-2347-6018
}

Received: 30 August 2019; Accepted: 2 October 2019; Published: 7 October 2019

\begin{abstract}
Climate change along with industrialization or urbanization, which uses materials with low water permeability and is accompanied by change in urban land use, are major reasons for frequent urban floods in many Chinese cities. Moreover, upgrading the drainage system can have numerous negative environmental impacts on the city, especially in districts with dense population and buildings. A new integrated urban water management (IUWM) strategy implemented in China, "sponge city," has gained significant attention in recent years. In this study, a novel framework is built to analyze the effectiveness of sponge city by 3D simulating urban inundation results and performing a cost-benefit analysis. Construction and maintenance fees are included in the costs list, and carbon reduction, air quality improvement, rainwater harvesting, and reduction of flood risk are included under benefits. The district of Nangang in Harbin city in Northeast China was chosen as a case study area. Finally, we conclude that the maximum precipitation of $49.82 \mathrm{~mm} / \mathrm{h}$ by sponge city can bring the inundation depth below a target depth in the target area. Further, though the sponge city project is not effective from a private perspective, it is effective from a social perspective.
\end{abstract}

Keywords: integrated urban water management; sponge city; social cost and benefit; GIS; life cycle

\section{Introduction}

Rapid urban expansion causes replacement of native vegetation areas, which facilitate rainwater interception, storage, and infiltration, with impervious surfaces, thereby increasing the rate and volume of surface runoff by rainwater. Intense storms in urban areas cause disastrous floods and enormous loss to human life and economy. For instance, on 21 and 22 July 2012, Beijing suffered the most severe storm and flood disaster in 61 years. The average rainfall in the city was $170 \mathrm{~mm}$ and in the city center was $215 \mathrm{~mm}$. The storm caused 79 deaths, 10754 cars submerged, and 10660 houses collapsed [1]. In 2014, China's Ministry of Housing and Urban-Rural Development published the technical guideline for sponge city implementation. A sponge city refers to integrated urban water management (IUWM), which combines the management of water supply, groundwater, wastewater, and storm water in cities [2]. Sponge city is not new in concept; Water sensitive urban design (WSUD) in Australia and Low impact development (LID) in US are similar concepts to sponge city from the current use of IUWM perspective [3], and storm water management is a subset of this concept directed at providing flood control, flow management, water quality improvements, and opportunities to harvest storm water to supplement mains water for non-potable uses. As vegetated swales, infiltration systems, permeable pavements, or bio-retention systems are used in WSUD, there are also some of 
prevalent technologies applied in sponge city construction, which include green roofs, rain gardens, water-permeable pavement, and vegetative swales.

Numerous studies have been conducted to analyze the benefits of sponge city or its technologies. Shao [4] performed this benefits analysis by combining the primary technologies used in the construction of a sponge city in Xiamen City. Their quantitative analysis suggested that urban greening can reduce carbon emissions by $66,266.7 \mathrm{t} / \mathrm{y}$, and the lake and river wetlands can reduce it by $962.8 \mathrm{t} / \mathrm{y}$. Furthermore, the use of rainwater resources in this sponge city can reduce carbon emissions by $2719.1 \mathrm{t} / \mathrm{y}$. Lin [5] showed that in Shanghai city, after building sponge city facilities in target residential communities, the accumulated carbon sink after 18.8 years can equal the total amount of carbon emissions. Additionally, in the subsequent lifespan, these sponge city facilities can function as carbon emission reduction system by absorbing greenhouse gases. In the last 11 years of the 30 year life cycle, the amount of net carbon emission absorbing benefit was calculated to be $25,407 \mathrm{~kg} \mathrm{CO}_{2} \mathrm{eq} / \mathrm{y}$. Mentens [6] showed that extensive roof greening (one type of green roofs) on just $10 \%$ of the buildings would result in a runoff reduction of $2.7 \%$ for that region and of $54 \%$ for the individual buildings. Furthermore, if $50 \%$ of regional builds roof were covered with extensive green, a reduction of $7.5 \%$ of the total runoff for the whole region could be achieved. Therefore, green roofs can be a useful tool for reducing urban rainfall runoff. Fassman [7] showed that by building green roofs with the layer thickness between 50 and $150 \mathrm{~mm}$, the runoff could be prevented if the precipitation is less than $25 \mathrm{~mm}$ in Auckland, New Zealand. Zhang [8] showed that in Beijing City, $2494 \mathrm{~m}^{3} / \mathrm{hm}^{2}$ overflow was reduced by green space, a total volume of 154 million $\mathrm{m}^{3}$ rainwater was stored in these urban green spaces and the total economic benefit was estimated to be 1.34 billion RMB (RMB: Chinese currency, US $\$ 1=$ RMB 6.83 present exchange rate, the same below)) in 2009.

There are also cost-benefit analysis studies on green roofs. Carter [9] mentioned that green roofs can provide both private and social benefits and concluded that the average social benefit from using green roofs totaled $\$ 34.95 / \mathrm{m}^{2}$ and private benefit was $\$ 26.70 / \mathrm{m}^{2}$ in Tanyard Branch watershed, Athens GA. Bianchini [10] concluded that from a social perspective, the total cost for building $600000 \mathrm{~m}^{2}$ green roofs with a lifespan of 40 years would be 8200-31,300 thousand RMB, and the total economic benefit would be 18,700-430,100 thousand RMB, and it would take six years for the investment to be paid back. From a personal perspective, the total cost for building $100 \mathrm{~m}^{2}$ green roofs with a lifespan of 40 years would be $43.4-368.1$ thousand RMB, and total benefit would be 760-6700 thousand RMB, and it would take fourteen years for the investment to be paid back.

As mentioned above, benefits from sponge city or its technologies are related to greenhouse gases absorbing, rainwater retention, air pollution removal, and energy reduction. However, benefit analysis from reducing flood inundation depth (flood control perspective) is insufficient to determine which benefit can bring reduction of flooding loss for local residents (Bianchini has calculated a storm flood risk reduction benefit from a large scale of England and Wales national flooding loss perspective). There are many flood inundation-simulating models, such as like SWMM [11], LISFLOOD-FP [12] and so on. However these models require large amounts of data such as on topography, sewer conveyance, and infiltration conditions, and some of these data can be difficult to obtain [13]. Owing to lack of data, the inundation simulating method introduced in this paper contains a simplified hydrologic model. This simulating method is mentioned by Zhang [14], and it consists of two parts, runoff calculation part and inundation result simulation part. 
In this study, we estimated the sponge city effect on the decrease of inundation depth in micro-scale by using a hydrologic model and GIS (Geographic Information System) simulation and analyzed the costs and benefits from private and social perspectives based on previous researches. Therefore, compared with previous work this paper tried to calculate precise benefit from sponge city in watershed scale and analyze the cost/benefit comparison more precisely.

\section{Methods}

\subsection{Scope and Limitations of the Assessment}

This paper assesses sponge city from storm water management perspective, considering the local context, accounting for environmental, economic, and social factors and it tried to add a new parameter-precipitation to optimal sponge city building area-for designers to refer to. The paper is organized in two parts: a storm flood risk reduction estimating model part and a cost-benefit analyzing part.

In the first part, inundated simulation model presented in this paper is a model suitable to simulate pluvial not fluvial flooding such as breach break flooding. This simulation helps us to find the most flood-risky place and the optimal sponge city building location. For pluvial flood, the reduction of risk analysis is usually estimated from people's safety risk, private property (including building and vehicle) and infrastructure loss perspective. In case of flood occurring, people are warned to stay at home when possible. However, analysis of flood loss has shown that people move in the surrounding of their home while pluvial flood is occurring; in particular, walking and driving in floodwaters are identified as the main danger during floods. However, as Monterusso [15] concluded that green roofs do not have anticipated runoff control effect of extremely heavy rainfall, this paper only considers reduction of people's safety risk and vehicle loss in a storm, not including building and infrastructure loss in extremely intensive rainfall situation. Flood risk is related to a number of factors not limited to rainfall or discharge but also including physical characteristics like elevation and depression, and the flood depth is one of the important elements [16]. We estimated the benefit from sponge city by quantifying the decrease of inundation depth, which can cause loss reduction. As mentioned above, the method mentioned by Zhang is introduced here; two assumptions in this method-precipitation was considered as average precipitation and drainage speed was treated as a unified design drainage capacity-are applied in this paper.

Costs and benefits are listed in life cycle, which include material production, construction, operation, and disassembly phase. Additionally, the input prices were gathered from different published and reliable sources as noted in the following section. Based on the cost-benefit analysis, benefit-cost ratio $(\mathrm{B} / \mathrm{C})$, defined as the ratio of benefits to costs, exceeding 1 is judged to be effective. In the cost-benefit analysis part, two scenarios (with and without external costs) are assessed in life cycle: life span is set at 40 years [17] and owing to the directive discount rate put forth by the Central Bank of PRC is between $3 \%$ and $4 \%$; Net Present Value (NPV) would be calculated by discount rate at $4 \%$ in this study. Moreover, the functional unit data was RMB per square meter $\left(\mathrm{RMB} / \mathrm{m}^{2}\right)$. The boundary and inventory are shown in Figure 1, inventory shown in private and external separated way is shown in Table 1 and the total work flow for this paper is shown in Figure 2. 
Table 1. Inventory shown in private and external separated way.

\begin{tabular}{|c|c|c|}
\hline & Cost & Benefit \\
\hline \multirow{5}{*}{ External } & Carbon emission cost from material production & Carbon reduction \\
\hline & Air pollution cost from material production & Air quality improvement \\
\hline & \multirow{2}{*}{ Carbon emission from equipment and transportation } & Reduction of flood risk \\
\hline & & Reduction of pollutant in runoff \\
\hline & Landfill cost & Aesthetics \\
\hline \multirow{3}{*}{ Private } & \multirow{2}{*}{ Construction fee } & Energy reduction- heating benefit \\
\hline & & Rainwater harvesting \\
\hline & Maintenance fee & Property value \\
\hline
\end{tabular}

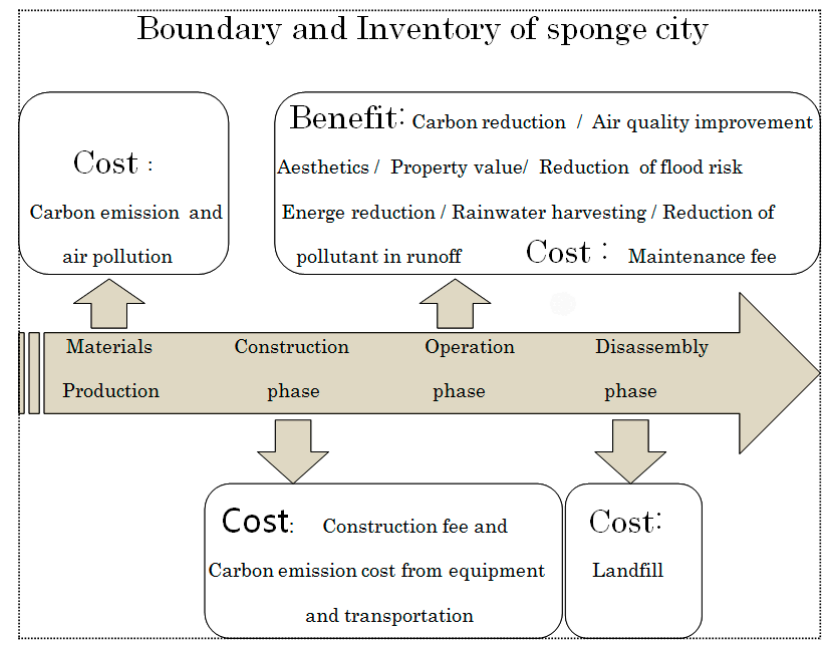

Figure 1. Boundary and inventory for sponge city cost-benefit analysis in life cycle.

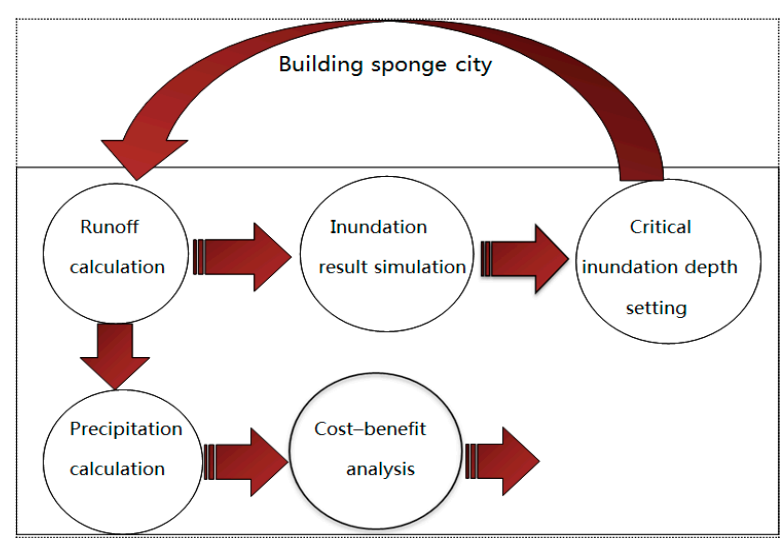

Figure 2. Workflow for this paper.

\subsection{Runoff Calculation}

A simplified hydrologic method: SCS-CN method [18] is used to calculate the runoff in this paper. The SCS-CN method is a method of estimating rainfall excess from rainfall and excess could be calculated by water balance theory (Figure 3). With regard to water balance, total precipitation consists 
of infiltration, evaporation, surface runoff, and drainage system runoff. Among these, only surface runoff contributes to urban inundation. The equation was shown by:

$$
R=T R-S-E
$$

$R$ : The amount of surface runoff (mm).

$T R$ : The amount of total runoff $(\mathrm{mm})$.

$S$ : The amount of drainage system runoff $(\mathrm{mm})$, which can be estimated by an average velocity of water drainage multiplied by storm duration. Design conveyance of the drainage system is used for the estimate of the average velocity of water drainage.

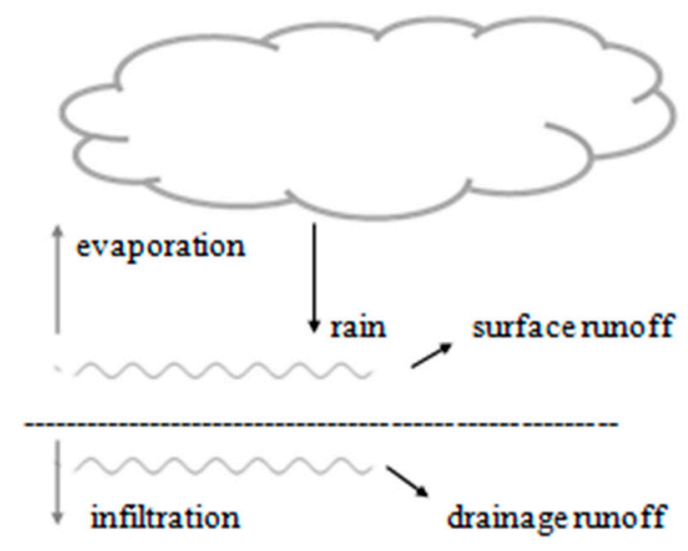

Figure 3. Schematic diagram of water balance theory.

$E$ : The amount of evaporation, which makes up approximately $0.5 \%$ of total rainfall volume of a three-day storm event [19] is not introduced here. TR is calculated by:

$$
\begin{aligned}
T R=\left\{\begin{array}{l}
(P-0.05 s r)^{2} /(P+0.95 s r), P \geq 0.05 s r \\
0, P \leq 0.05 s r
\end{array}\right\} \\
S r=25400 / C N-254
\end{aligned}
$$

$P$ : The amount of precipitation $(\mathrm{mm})$.

Sr: The potential maximum soil moisture retention.

$C N$ : The runoff curve number, which embodies the empirical analysis on impact of soil infiltration capability and the type of land use. The amount of surface runoff (R) can be calculated by Equations (1)-(3).

\subsection{Inundation Result Simulation}

This simulation was conducted by ArcGIS software with elevation data DEM (Digital Elevation Model). Its operating principle was to use ArcGIS to extract boundary and divide basic calculating unit, sub-catchment, and then calculate the runoff volume for each sub-catchment by the confluence order. The detailed steps were shown by: 
(a) Obtaining Depression Area from DEM

Pits should be filled using ArcGIS hydrology tools. We assume that the filled DEM is the same as the area where flow fills all the depressions. Then, depressions are calculated by using filled DEM minus original DEM.

(b) Dividing Sub-Catchment, Extract Boundary and Find the Confluence Order

A D8 algorithm was used to calculate flow direction and divide the sub catchment. In the first step, hydrological tools were used in ArcGIS to calculate the flow direction and flow accumulation. In the second step, a threshold was set for flow accumulation to extract the stream (selecting depressions whose flow accumulations are greater than the threshold as flooded depressions), making sure to define all depressions on the extracted stream as the sub-catchment outlet node. Depressions not on the extracted stream were ignored because there is little water flow to them, and these depressions seldom become inundated. The depressions on the extracted stream were the potential inundated area, and the maximum storage volume and storage curve of these depressions were obtained using ArcGIS 3D analysis tools. In the third step, the sub catchment was divided based on flow direction, flow accumulation, and the defined node boundary was obtained by: Data Management Tools $>>$ Features $>>$ Feature to Polygon. There were two kinds of sub-catchment outlet node-depression point on the stream and the stream joint. Thus, the upstream catchment area for each depression and the convergence order between these depressions were obtained. The sub-catchment area was calculated using the ArcGIS attribute table Calculate Geometry Tool, and the confluence order of the depressions was obtained by the stream flow direction.

(c) Calculating the Runoff Volume for each Sub-Catchment

According to the order from upstream to downstream, surface runoff volume for each depression was calculated by:

$$
V_{i}=R \times A_{i}
$$

$V_{i}$ : The surface runoff volume for depression $i$.

$A_{i}$ : The catchment area for depression $i$.

$R$ : the amount of surface runoff $(\mathrm{mm})$.

The surface runoff volume $V_{i}$ of each depression was compared with the maximum storage that the depression can hold. When $V_{i}$ was found to be less than this maximum, it was taken as the final inundation volume of the depression and its inundation area and depth were calculated by its storage curve. Alternatively; when $V_{i}$ exceeded the maximum water storage, the depression was assumed to have been completely filled and the excess water was transferred along the direction of the river network to the next depression, therefore depth and area of the depression are the final inundation results (Figure 4). Uncertainty of this modeling procedures are estimation of $\mathrm{CN}$ value and division of sub-catchment. $\mathrm{CN}$ value was estimated from empirical observation and sub-catchment was divided by ArcGIS software based on elevation information. Therefore both of them should be calibrated and validated by practical inundation result. 


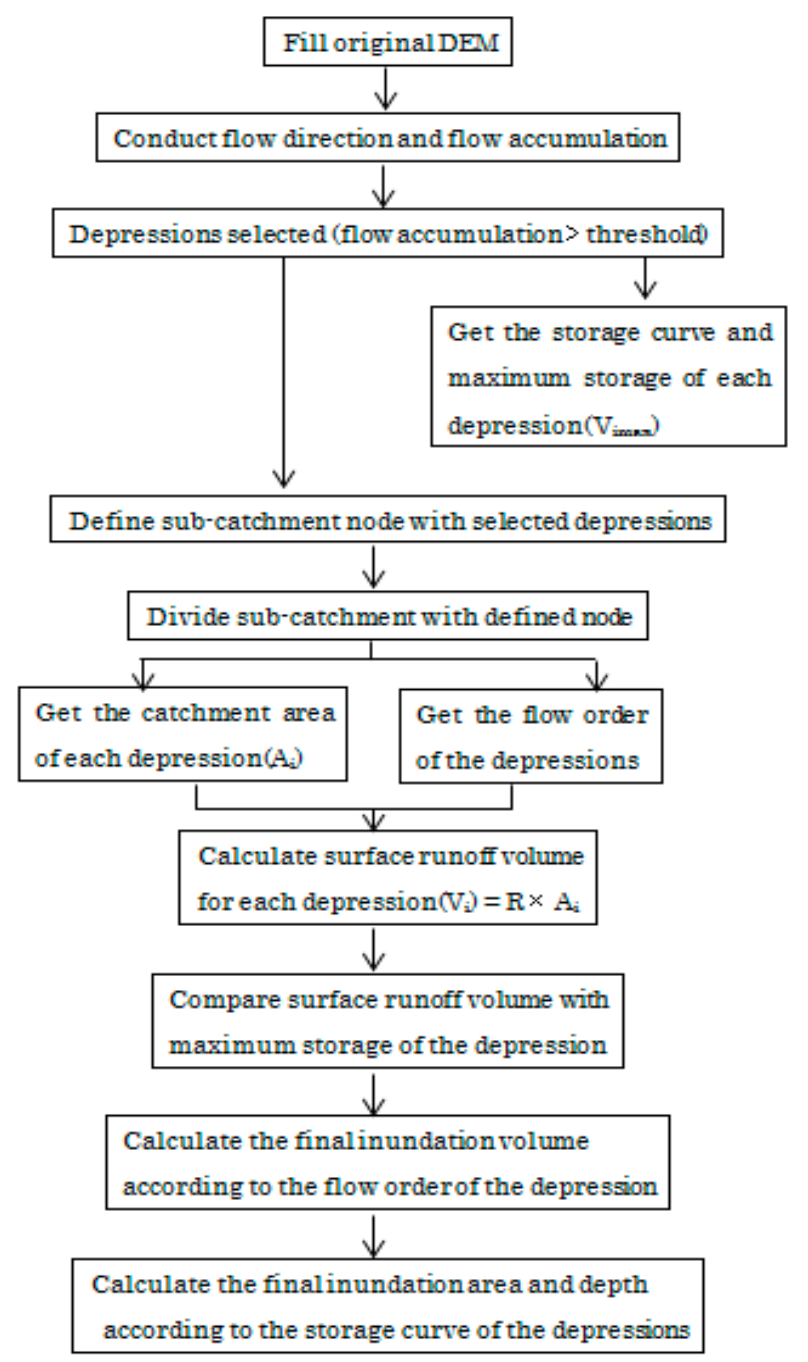

Figure 4. Workflow for inundating simulation.

\subsection{Critical Inundation Depth Setting}

Sponge city was considered as a countermeasure to decrease the flood risk, therefore the direct effect on decrease of pedestrians' injury or death and parking or driving cars water-invaded in storm flood is expected. Arrighi [20] set the critical flood depth for pedestrians at $1.7 \mathrm{~m}$ tall (the average Italian adult) and for cars at $300 \mathrm{~mm}$. We set $1.61 \mathrm{~m}$ tall (the average Chinese adult) as critical flood depth for pedestrians and $300 \mathrm{~mm}$ for cars. In fact for cars' critical depth, we could obtain the same result from empirical analysis: driving out is dangerous when rainwater depth exceeds half of car's tire (Figure 5). The specifications of car tire from Standardization Administration of China are shown in Table 2. The specification was explained: take specification of " $155 \mathrm{~mm} / 65 \mathrm{R} 13$ " as sample, $155 \mathrm{~mm}$ is cross section width; 65 is the ratio of rubber thickness to cross section width (\%); R means radial tire; 13 (inch) is wheel diameter. Therefore the outer diameter of a tire could be calculated by: $155 \mathrm{~mm} \times$ $65 \% \times 2+13$ (inch) $\times 25.4 \mathrm{~mm}=531.7 \mathrm{~mm}$. Referring to Table 2 , we observed that the average value of outer semi-diameter is $300 \mathrm{~mm}$.

Furthermore, there is a similar critical depth setting from JAF (Japan Automobile Federation) in Japan, which demonstrates that driving a car in $300 \mathrm{~mm}$ depth water with a speed of $30 \mathrm{~km} / \mathrm{h}$ could cause the engine room to become water-invaded [21]. However, this test did not consider the effect from other cars driving in the water at the same time. 


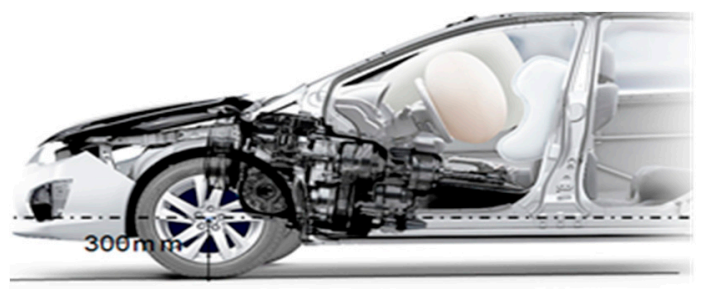

Figure 5. Image of water-invaded car.

Table 2. Specifications of car tire list.

\begin{tabular}{ccc}
\hline Specification & Outer Diameter & Outer Semi-Diameter \\
\hline $155 \mathrm{~mm} / 65 \mathrm{R} 13$ & $531.7 \mathrm{~mm}$ & $265.85 \mathrm{~mm}$ \\
\hline $185 \mathrm{~mm} / 60 \mathrm{R} 14$ & $577.6 \mathrm{~mm}$ & $288.8 \mathrm{~mm}$ \\
\hline $195 \mathrm{~mm} / 55 \mathrm{R} 15$ & $595.5 \mathrm{~mm}$ & $297.75 \mathrm{~mm}$ \\
\hline $185 \mathrm{~mm} / 65 \mathrm{R} 14$ & $596.1 \mathrm{~mm}$ & $298.05 \mathrm{~mm}$ \\
\hline $175 \mathrm{~mm} / 70 \mathrm{R} 14$ & $600.6 \mathrm{~mm}$ & $300.3 \mathrm{~mm}$ \\
\hline $185 \mathrm{~mm} / 65 \mathrm{R} 15$ & $621.5 \mathrm{~mm}$ & $310.75 \mathrm{~mm}$ \\
\hline $205 \mathrm{~mm} / 55 \mathrm{R} 16$ & $631.9 \mathrm{~mm}$ & $315.95 \mathrm{~mm}$ \\
\hline $225 \mathrm{~mm} / 40 \mathrm{R} 18$ & $637.2 \mathrm{~mm}$ & $318.6 \mathrm{~mm}$ \\
\hline $235 \mathrm{~mm} / 60 \mathrm{R} 16$ & $688.4 \mathrm{~mm}$ & $344.2 \mathrm{~mm}$ \\
\hline
\end{tabular}

\section{Case Study}

\subsection{Study Area}

The district of Nangang in Harbin city is located in $126^{\circ} 34^{\prime}-126^{\circ} 41^{\prime} \mathrm{E}$ and $45^{\circ} 41^{\prime}-45^{\circ} 46^{\prime} \mathrm{N}$. It lies in mid-south section of Harbin city, Heilongjiang province, in Northeastern China (Figure 6) and has a temperate continental monsoon climate. Annual average precipitation is $569.1 \mathrm{~mm}$. Most drainage system in Harbin is confluence pipe and was first established in 1904, and the main part of the city has $1161 \mathrm{~km}$ of municipal, sewer drains, 24,483 check wells, 14,381 rain wells, and a drainage network penetration rate of $66.17 \%$, drainage system design conveyance capacity was $18 \mathrm{~mm} / \mathrm{h}$. Harbin's municipal drainage pump stations provide a drainage capacity of $135 \mathrm{~m}^{3} / \mathrm{s}$. According to standards to protect against moderate rainfall $(25 \mathrm{~mm} / \mathrm{h})$, the city requires a drainage capacity of $185 \mathrm{~m}^{3} / \mathrm{s}$. Therefore, serious waterlogging occurs in the city with only moderate precipitation. Statistics show that Harbin has 17 large waterlogging regions with $0.5-1.0 \mathrm{~m}$ water depth lasting 1-3 $\mathrm{h}$ [22].

Topographic input is a 1:2000 Nangang district contour map. The following steps were conduct in ArcGIS Software.

(a) Convert the contour map into TIN-based DEM by conducting: [3D analyst Tools] $>>$ [Data Management] $>>$ [TIN] $>>$ [Create TIN]; and then convert TIN-based DEM into raster DEM at $2 \mathrm{~m}$ resolution by conducting: [3D analyst Tools] $>>$ [Conversion] $>>$ [From TIN] $>>$ [TIN to Raster]; buildings heights are not considered in DEM generation. Therefore we obtained the raster DEM data of Nangang district, and it has an elevation range 117.1-223.1 $\mathrm{m}$ above sea level (Figure 6).

(b) Conduct [Spatial analyst Tools] $>>$ [Hydrology] $>>$ [Fill] $>>$ [Flow Direction] $>>$ [Flow Accumulation] $>>$ [Basin], then conduct: [Conversion Tools] $>>$ [From Raster] $>>$ [Raster to Polygon] (threshold value set as $1 \% \times$ maximum accumulation) (Figure 7).

(c) Conduct [Data Management Tools] $>>$ [Raster] $>>$ [Raster Processing] $>>$ [Clip] (Figure 8). Based the DEM analyzing, we found that north (up) area is lower than south (down) area, and stream flows from south to north. This is also verified by Zhang [12]. We clipped most serious waterlogging area in this district (green part) DEM (Figure 8) to simulate the inundation result. Due to the boundary 
being extracted from ArcGIS analysis, green part area is an independent basin, no coming water from upstream. Then we conducted the orders mentioned in 2.3 with DEM of green part, obtained the storage curve and maximum storage volume of each depression on the stream, and delineated watershed (sub-catchment) by defining outlet nodes.

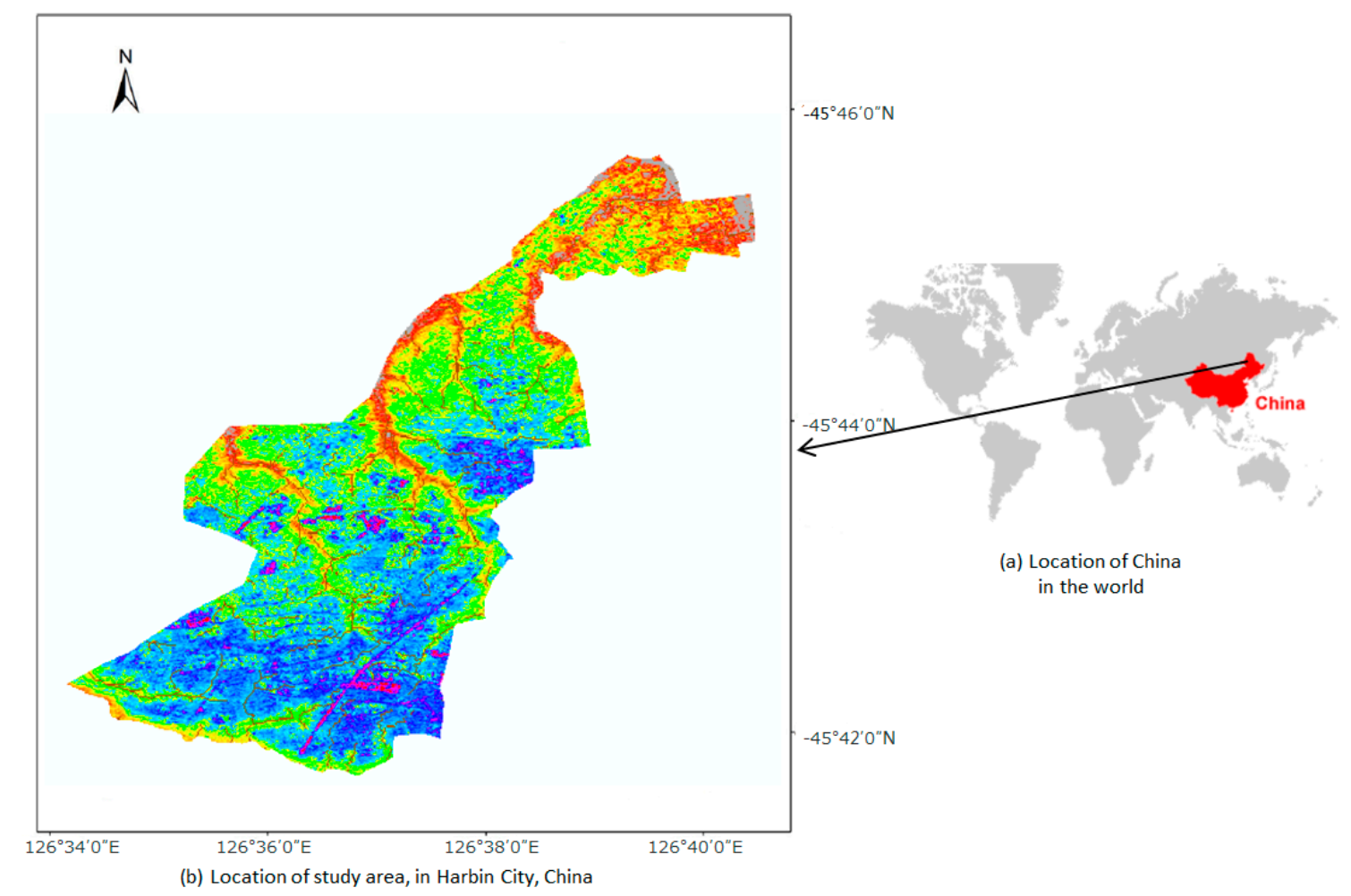

Figure 6. Study area of Nangang district, Harbin City, in China.
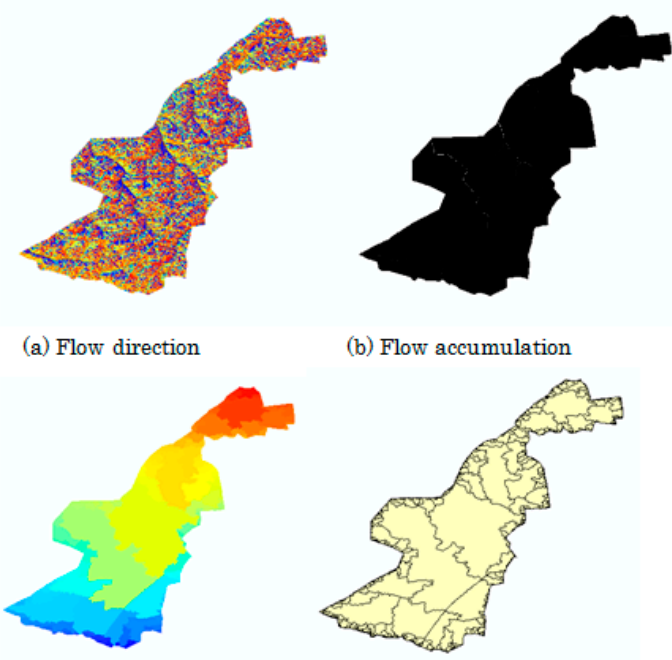

(b) Flow accumulation

(c) Basin

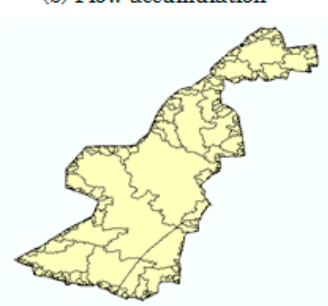

(d) Catchment distribution

Figure 7. Hydrology analysis results including (a-c) and boundary extracted result (d) by ArcGIS. 

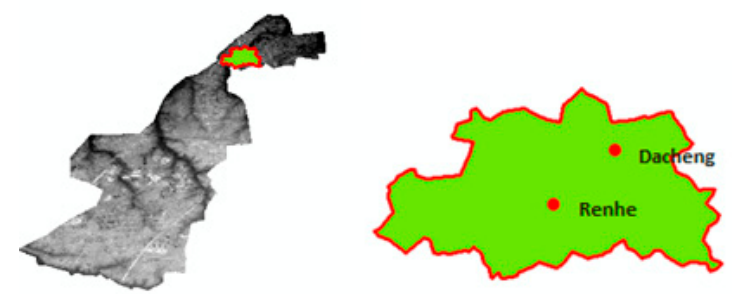

Figure 8. Target area (green) and Renhe, Dacheng depressions.

We also concluded that the green part area is $8.6 \mathrm{~km}^{2}$; the percentage of impervious area to this area is estimated as $69.6 \%$ based on GIS analysis of land use maps; curve number is 91 . We noticed that no depression existed on the extracted stream whose maximum inundation depth surpassed $1.61 \mathrm{~m}$ (divided maximum storage volume by corresponding inundation area in storage curve), which means low risk for people's safety. Then we considered car's water-invaded risk.

\subsection{Calculation of Critical Precipitation Leading to High Risk for Parking or Moving Cars (Water Invaded)}

As mentioned above, the $300 \mathrm{~mm}$ inundation depth was the critical value leading to car's becoming water invaded. Besides inundation depth, the area of inundation is another crucial factor. Small area inundation spots were excluded because they would not lead to massive car water-invasion. Based on observation of maximum storage volume of each depression, we found that maximum storage volumes of Renhe depression and Dacheng depression (Figure 8) are huge and very easy to become large inundation areas by heavy rainfall (two depressions are confluence spots of the obtained stream). Therefore we tried to obtain the precipitation value in which case Renhe depression and Dacheng depression would be inundated at $300 \mathrm{~mm}$.

It was very difficult to obtain the just $300 \mathrm{~mm}$ inundation depth practical situation and its precipitation data at that time, therefore we assumed a storm which leads to $300 \mathrm{~mm}$ (or close) depth inundation at Renhe and Dacheng depression. In order to make the simulated result close to the practical conditions, we simulated firstly the practical storm event inundation result that took place on 4 June 2009, which was a two-hour duration event, with rainfall amount $15.4 \mathrm{~mm}$ in the first hour and $42.1 \mathrm{~mm}$ in the second. The input data was shown in Table 3 and the simulated results at Renhe and Dacheng streets were shown in Table 4. Then we simulated the assumed storm event; considering the difference (error) between the simulated and the measured results (Table 4) in practical storm simulation, we took the average depth (between simulated depth and measured depth) as the starting depth. For example, for Renhe street, the average depth for measured and simulated depth was $231 \mathrm{~mm}$, and the difference between this value and $300 \mathrm{~mm}$ inundation depth is $69 \mathrm{~mm}$. We knew the corresponding elevation of "input surface" (ArcGIS 3D Analysis tools) when the inundation volume is $584 \mathrm{~m}^{3}$ (Table 4), therefore we could obtain the target inundation volume by adding $7 \mathrm{~cm}$ to the elevation of the "input surface" mentioned above from ArcGIS 3D analysis tools. After target inundation volume was obtained, the target inundation area could be calculated by this volume and its storage curve. Conduct the same steps at Dacheng street, and the requirement satisfied volume and area could be calculated. After target volumes at two streets were obtained, we conducted the order mentioned in 2.3 by enlarging the surface runoff $(R)$ gradually from $7.29 \mathrm{~mm}$ (surface runoff occurred in practical storm inundation situation) until these target volumes (or close) arising in Renhe and Dacheng streets respectively. The simulation has shown that Renhe Street reached $300 \mathrm{~mm}$ inundation depth first, and then Dacheng Street reached. Surface runoffs (R) at that time were recorded as $11.42 \mathrm{~mm}$ and $12.58 \mathrm{~mm}$, respectively. Adding to drainage capacity (S) $18 \mathrm{~mm}$, with potential maximum soil moisture retention (sr) $25.12 \mathrm{~mm}$ and equation (1b), (1c), we obtained the corresponding precipitation as $47.6 \mathrm{~mm} / \mathrm{h}$ and $48.2 \mathrm{~mm} / \mathrm{h}$ respectively. We took the greater one (benefit analysis below was calculated based on the worst situation). Used or obtained hydrologic data and final inundation results were shown in Tables 5 and 6 respectively. 
Table 3. Data used in practical storm event simulation.

\begin{tabular}{cc}
\hline Input Data & Value \\
\hline Precipitation & $42.1 \mathrm{~mm} / \mathrm{h}$ \\
\hline $\mathrm{CN}$ & 91 \\
\hline $\mathrm{sr}$ & $25.12 \mathrm{~mm}$ \\
\hline Total runoff (TR) & $25.29 \mathrm{~mm} / \mathrm{h}$ \\
\hline Average velocity of water drainage & $18 \mathrm{~mm} / \mathrm{h}$ \\
\hline Surface Runoff (R) & $7.29 \mathrm{~mm} / \mathrm{h}$ \\
\hline
\end{tabular}

Table 4. Simulated and measured results in practical storm at Renhe and Dacheng streets.

\begin{tabular}{ccc}
\hline Results & Renhe Street & Dacheng Street \\
\hline measured depth & $200 \mathrm{~mm}$ & $200 \mathrm{~mm}$ \\
\hline simulated depth & $262 \mathrm{~mm}$ & $182 \mathrm{~mm}$ \\
\hline measured area & $2500 \mathrm{~m}^{2}$ & $2000 \mathrm{~m}^{2}$ \\
\hline simulated area & $2231 \mathrm{~m}^{2}$ & $2596 \mathrm{~m}^{2}$ \\
\hline measured volume & $500 \mathrm{~m}^{3}$ & $400 \mathrm{~m}^{3}$ \\
\hline Simulated volume & $584 \mathrm{~m}^{3}$ & $472 \mathrm{~m}^{3}$
\end{tabular}

Table 5. Data used or obtained in assumed storm simulation.

\begin{tabular}{cc}
\hline Input Data & Value \\
\hline Precipitation & $48.2 \mathrm{~mm} / \mathrm{h}$ \\
\hline $\mathrm{CN}$ & 91 \\
\hline $\mathrm{sr}$ & $25.12 \mathrm{~mm}$ \\
\hline Total runoff (TR) & $30.58 \mathrm{~mm} / \mathrm{h}$ \\
\hline Average velocity of water drainage & $18 \mathrm{~mm} / \mathrm{h}$ \\
\hline Surface Runoff $(\mathrm{R})$ & $12.58 \mathrm{~mm} / \mathrm{h}$ \\
\hline
\end{tabular}

Table 6. Simulated inundation results of assumed storm; (The depth values shown here are adjusted depth value, not the proper simulated depth).

\begin{tabular}{ccc}
\hline Simulation Results & Renhe Street & Dacheng Street \\
\hline Depth & $359 \mathrm{~mm}$ & $301 \mathrm{~mm}$ \\
\hline Area & $5697 \mathrm{~m}^{2}$ & $4876 \mathrm{~m}^{2}$ \\
\hline Volume & $2218 \mathrm{~m}^{3}$ & $1456 \mathrm{~m}^{3}$ \\
\hline
\end{tabular}

\subsection{Scenario with Building Sponge City in Inundation Area}

In order to mitigate serious waterlogging, a sponge city project was designed in target area. Considering the target area is located in dense buildings district, housing demolition and relocation (making space for building rain garden or water-permeable pavement) fee are very high, therefore building green roofs on existing mansions is optimal technology.

(a) Detailed Investment Amount, Construction Area, and Construction Plan

According to the Bid Winning Announcement of Qunli Healthy Ecological Garden [23] (completed sample program of sponge city in Daoli district, Harbin city), the total winning price was 101 million $\mathrm{RMB}$, including construction fee 83 million RMB (construction period is 1 year) and maintenance fee 
is 18 million RBM. Here we assumed that an equal construction fee (83 million RMB) sponge city was designed to be built in the case study area (construction period is 1 year). Due to the building fee for Extensive Green Roofs being low and its maintenance convenient, Extensive Green Roof technology is recommended for building green roofs on top of old buildings. Based on previous researches on Extensive Green Roofs (Table 7), the unit construction fee was introduced as $141 \mathrm{RMB} / \mathrm{m}^{2}$ and maintenance fee was $12 \mathrm{RBM} / \mathrm{m}^{2}$ (introduced by Beijing standard). Therefore 592 thousand $\mathrm{m}^{2}$ Extensive Green Roofs could be built in this study. Considering the practical serious waterlogging area location (Renhe and Dacheng street), the place in upstream of Renhe and Dacheng streets is anticipated to be the optimal construction place. Detailed construction plan was shown in Figure 9.

Table 7. Previous researches on Extensive Green Roofs.

\begin{tabular}{cccc}
\hline Existing Study & Country & Unit Construction Fee & Unit Maintenance Fee \\
\hline Wan Jing (2009) [24] & $\begin{array}{c}\text { China } \\
\text { (Shang-hai) }\end{array}$ & $\begin{array}{c}50-60 \\
\left(\mathrm{RMB} / \mathrm{m}^{2}\right)\end{array}$ & $\begin{array}{c}14.5-20.75 \\
\left(\mathrm{RMB} / \mathrm{m}^{2}\right)\end{array}$ \\
\hline $\begin{array}{c}\text { Beijing Institute of Landscape } \\
\text { (2014) [25] }\end{array}$ & $\begin{array}{c}\text { China } \\
\text { (Beijing) }\end{array}$ & $\begin{array}{c}141 \\
\left(\mathrm{RMB} / \mathrm{m}^{2}\right)\end{array}$ \\
\hline Bianchini (2012) [10] & America & $\begin{array}{c}800-3360 \\
\left(\mathrm{RMB} / \mathrm{m}^{2}\right)\end{array}$ & $\begin{array}{c}\left.\mathrm{R}^{2}\right) \\
\left(\mathrm{RMB} / \mathrm{m}^{2}\right)\end{array}$ \\
\hline \multirow{2}{*}{ English Nature (2003) [26] } & England & $180-220$ & $30-50$ \\
& & $\left(\mathrm{RMB} / \mathrm{m}^{2}\right)$ & $\left(\mathrm{RMB} / \mathrm{m}^{2}\right)$ \\
\hline
\end{tabular}

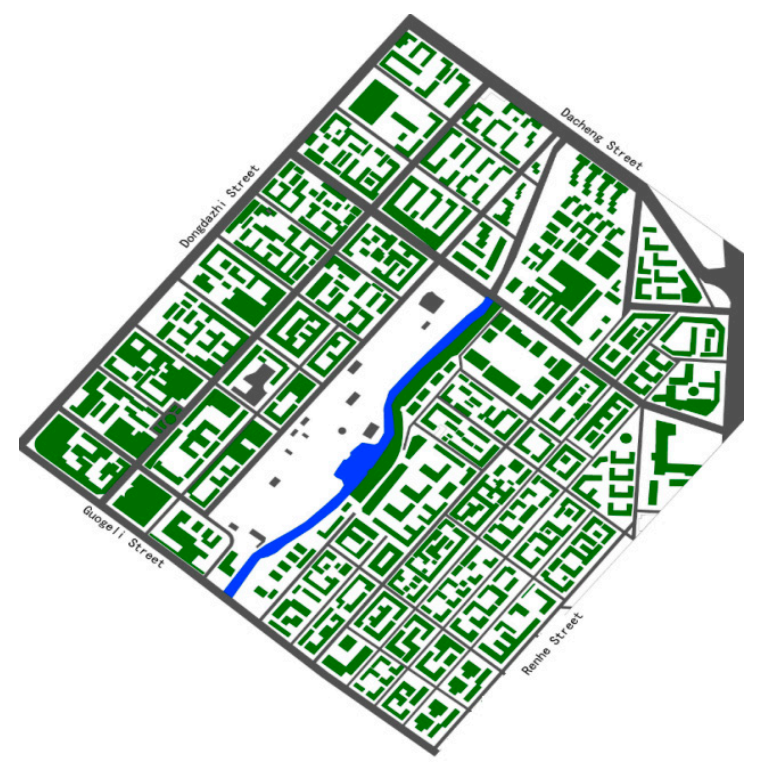

Figure 9. Construction location and detailed construction plan.

(b) Extensive Green Roofs technology

Extensive Green Roofs contains three layers, of which Growing media is on the top, Drainage layer and Waterproofing layer are beneath, and all the layers are built on top of approved deck or concrete (Figure 10). Vegetation of sedum lineare Thunb is used in growing media, and the thickness of growing media is designed as $10 \mathrm{~cm}$. 


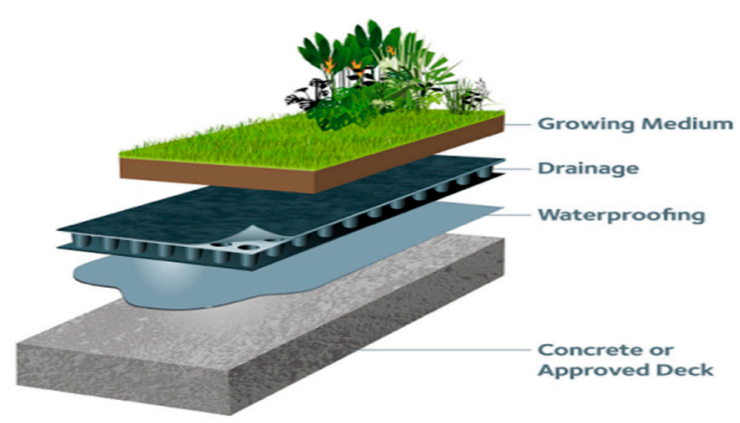

Figure 10. Extensive Green Roof technology.

(c) Calculation of Critical Precipitation in Scenario with Sponge City

Owing to the construction of Extensive Green Roofs, the impervious area percentage to target area is reduced to $62.7 \%$ from $69.6 \%$, the value of $\mathrm{CN}$ is estimated to decrease to 90 from 91 , and sr is estimated to increase to 28.22 from 25.12. In order to find the critical state and obtain the same inundation result shown in Table 6 (due to water absorbing by sponge city, the inundation result does not change even with a greater precipitation), total runoff (TR) should be satisfied with $30.58 \mathrm{~mm}$. Therefore, with TR $=30.58 \mathrm{~mm}$, $\mathrm{sr}=28.22 \mathrm{~mm}$ and Equation $(1 \mathrm{~b})$, the critical precipitation was calculated as $49.82 \mathrm{~mm} / \mathrm{h}$. This result indicates that by building a sponge city described above, the critical value of precipitation we can control the inundation depth below $300 \mathrm{~mm}$ is $49.82 \mathrm{~mm} / \mathrm{h}$, and if the precipitation surpasses this value, only this sponge city cannot reduce the flood risk of cars becoming water-invaded.

As mentioned above, the inundation depth is controlled under $300 \mathrm{~mm}$, which is low risk for car water-invasion and whose loss was huge in many urban waterlogging disasters. Therefore, the decrease of car loss is an obvious benefit for the cost-benefit analysis.

\subsection{Cost-Benefit Analysis}

Private cost-benefit and social (including private and external) cost-benefit scenarios are analyzed in this part. The costs and benefits are shown in:

\subsubsection{Private Costs}

Private costs include two parts: construction fee and maintenance fee. Both of them were shown in 3.3.

\subsubsection{Private Benefits}

(a) Energy reduction-heating benefit

Owing to Harbin City being located in a cold area, the proportion of cooling degree days in summer to heating degree days in winter is small [27], therefore we only considered the heating energy saving in winter in this case. Extensive Green roofs save 0.22 therms $/ \mathrm{m}^{2}$ in heating (natural gas) energy, and therms price was introducted as $6.83 \mathrm{RBM} /$ therm [28].

(b) Rainwater Harvesting

Annual average precipitation is $569 \mathrm{~mm}$ in Harbin City. By building green roofs, $20 \%$ of annual precipitation (falling on green roofs area) could be restored and reused in China [29]. Owing to rainwater not receiving purification treatment in many Chinese cities, water quality improvement is not included in this study. Harvesting rainwater could be used to water gardens or streets (a method to decrease the temperature of the street and fix the dust, used in Chinese cities in summer). Non-potable water price in Harbin is $1.8 \mathrm{RMB} / \mathrm{m}^{3}$. 
(c) Property Value

Extensive Green Roofs can make property value increase by $3.5 \%$ of the property [26]. A 10,000 $\mathrm{RBM} / \mathrm{m}^{2}$ property value was introduced (existing mansion price in market of Harbin).

\subsubsection{External Costs}

(a) Carbon emission cost from material production

For $1 \mathrm{~m}^{2}$ of Extensive Green Roofs, $2.59 \mathrm{~kg}$ polymer is required; $1 \mathrm{~kg}$ of polymer production releases $1.7 \mathrm{~kg}$ of carbon $\left(\mathrm{CO}_{2}\right)[5,25]$. Carbon tax was set as $60 \mathrm{RMB} /$ ton (carbon emission allowances trading price in Beijing market) (the same below).

(b) Air Pollution Cost from Material Production

The production of polymers has three basic steps: melting of the raw material, shaping of the molten material, and solidification of the molten to the desired shape. Therefore it needs high amounts of energy to increase the temperature to more than $120^{\circ} \mathrm{C}$, to melt the raw material to facilitate the shaping. After providing the desired form, the material must be cooled down to accelerate solidification. The energy sources and chemicals in the manufacture process of polymers release toxic substances to the air [30]. A total of $123 \mathrm{RMB} / \mathrm{m}^{2}\left(\$ 18.03 / \mathrm{m}^{2}\right)$ was introduced as the unit data in this study [10].

(c) Carbon Emissions from Equipment and Transportation

Carbon emission cost resulted from construction machine operation and material transportation process. Unit data was derived from previous study [31] and introduced as $0.05 \mathrm{RMB} / \mathrm{m}^{2}$.

\section{(d) Landfill Costs}

The disposal phase of green roofs has different options. Materials can be recycled, reused, or landfilled. However, many cities do not have the required technology to undertake the recycling process in China. Hence, this analysis considered the worst case: green roof layers are landfilled without any treatment process. Jamasb [32] estimated the cost as $85.38 \mathrm{RMB} /$ ton $(\$ 12.5 /$ ton $)$ of waste management in United Kingdom (UK). Wang [33] calculated the average waste fulfill fee as $23.61 \mathrm{RMB} /$ ton (\$3.63/ton) in China. The amount of polymers used in extensive green roofs is $2.59 \mathrm{~kg}$ for $1 \mathrm{~m}^{2}$, therefore the unit cost by landfilling without energy recovery for Extensive Green Roofs is $0.06 \mathrm{RMB} / \mathrm{m}^{2}$ (The result from Wang was adopted).

\subsubsection{External Benefits}

\section{(a) Carbon Reduction Benefit}

Unit data for Sedum lineare average carbon absorbing capacity was derived from previous researches [25,34], estimated as $0.06 \mathrm{RBM} / \mathrm{m}^{2}$.

(b) Air Quality Improvement Benefit

Air quality is related to the amount of dust, particulates, and nitrates (NOx) in the air. However improvement on air quality here was limited to the mitigation of nitrogen oxide (NOx) from the commercial standard due to Nitrogen oxide emission allowances are currently traded in the US [17]. Unit data was derived from previous studies as $0.25 \mathrm{RMB} / \mathrm{m}^{2}[9,10,17,34]$, in which NOx emissions tax was set as $23051 \mathrm{RMB} /$ ton (\$3375/ton).

(c) Reduction of Pollutant in Runoff

After setting up of green roofs, the pollutant in runoff could be removed by the runoff reduction. The pollutants COD and nitrogen were calculated in this study. According to previous study [5], unit data was derived as $0.03 \mathrm{RMB} / \mathrm{m}^{2}$. 
(d) Aesthetics

This methodology asks individuals for their willingness to pay extra for a given good or accept compensation for a given harm. It is assumed that the aesthetics benefit obtained from Extensive Green Roofs is $3.5 \%$ of the green roof private cost [10] (construction fee).

(e) Reduction of Flood Risk Benefit

In our case study, the reduction of Vehicle Wading Insurance [35] compensation owing to the reduction of cars water-invaded is a benefit. According to the data collected from Chinese insurance companies PING AN (PING AN INSURANCE COMPANY) and PICC (People's Insurance Company of China), in 2012, 2017, and 2018 (no big storm occurred in other years) there were in total 763 cars claimed for Wading Insurance from Nangang district (Table 8). Therefore from 2012 to 2018, between 7 years there are 109 cars/year on average received the compensation. The maximum compensation for one car was 50,000 RMB. The total reduction of flood loss benefit was calculated as 5.45 million RMB. Unit data could be obtained dividing total benefit by green roof area. It was calculated as $9.2 \mathrm{RMB} / \mathrm{m}^{2}$. In fact, according to insurance company instruction, there are three grades for water-logged cars. First grade is water invasion in the engine room; second grade is car chair is inundated but water does not reach the control panel; and third grade is control panel is inundated. For first grade, due to the water not being clean but dirty and filled with pollutants, many water-invaded parts are replaced by a new one in repair factory (car holders are inclined to use the compensation up). Additionally, only grade 1 belongs to compensation range; grade 2 and grade 3 are not included in insurance company compensation range, which implies that our target inundation depth setting matches the insurance company condition. Using insurance perspective to evaluate water management is not new as a concept. González Dávila [36] concluded that insurance might be very important to society since it affects the redistribution of the cost of damage. Furthermore, using insurance claim data to conduct analysis is not new either. Spekkers [37] analyzed the relation between water-related insurance damage claims and rainfall extremes for Netherlands.

Table 8. Claims for Vehicle Wading Insurance from PING AN and PICC Insurance companies.

\begin{tabular}{cccc}
\hline Company & $\mathbf{2 0 1 2}$ & $\mathbf{2 0 1 7}$ & $\mathbf{2 0 1 8}$ \\
\hline PING AN & 248 & 120 & 88 \\
\hline PICC & 143 & 101 & 67 \\
\hline Average & & 109 car/year \\
\hline
\end{tabular}

\subsubsection{Other Categories}

There are some categories that may be relevant in particular green roof applications, which however were not included in this analysis because of a lack of reliable data or incompatibility of the benefit with the type of green roof used in this study. For example, we could not collect the reliable data to calculate the benefit of heat island effect mitigation in Harbin (cold area), so this benefit is not included in this study; urban green space and habitat is clearly a benefit provided by green roofs. While accessible rooftops provide the building owner or tenant with additional space for recreation or growing vegetables, the roof designed in this study does not perform these functions.

Finally, all private costs/benefits and external costs/benefits unit data were shown in Tables 9 and 10 respectively. 
Table 9. Private costs $\left(\mathrm{RMB} / \mathrm{m}^{2}\right)$ and benefits $\left(\mathrm{RMB} / \mathrm{m}^{2}\right)$ from Extensive Green Roofs.

\begin{tabular}{cccc}
\hline Cost Categories & Unit Cost & Benefit Categories & Unit Benefit \\
\hline Construction fee & 141 & Energy reduction- heating benefit & 1.5 \\
\hline \multirow{2}{*}{ Maintenance fee } & 12 & Rainwater harvesting & 0.2 \\
\cline { 3 - 4 } & & Property value & 350 \\
\hline
\end{tabular}

Table 10. External costs $\left(\mathrm{RMB} / \mathrm{m}^{2}\right)$ and benefits $\left(\mathrm{RMB} / \mathrm{m}^{2}\right)$ from Extensive Green Roofs.

\begin{tabular}{cccc}
\hline Cost Categories & Unit Cost & Benefit Categories & Unit Benefit \\
\hline $\begin{array}{c}\text { Carbon emission from } \\
\text { materials production }\end{array}$ & 0.3 & Carbon reduction & 0.06 \\
\hline $\begin{array}{c}\text { Air pollution from } \\
\text { materials production }\end{array}$ & 123 & Air quality improvement & 0.25 \\
\hline $\begin{array}{c}\text { Carbon emission from } \\
\text { equipment and } \\
\text { transportation }\end{array}$ & 0.05 & Reduction of pollutant in runoff & 0.2 \\
\hline Landfill cost & 0.06 & Aesthetics & 5 \\
\hline
\end{tabular}

\subsection{Results}

We make comparison analysis between costs and benefits mentioned above without or with two scenarios of external costs and benefits. The comparison analysis results are shown in Figure 11. According to the comparison analysis, we found that without considering external costs and external benefits, at starting time (except the first year), private benefits (PB) are greater than private costs (PC); however from the 33th year, private costs (PC) became greater than private benefits (PB); the key reason is maintenance fee per year is greater than variable private benefit (PB) per year, causing costs to surpass benefits from the 33th year; considering external costs and external benefits, except the first year, social benefits (SB) are greater than social costs (SC) in life span. Obviously, from a private perspective, this project is not effective; then from social perspective, by calculating the B/C and NPV with discount rate as $4 \%$ mentioned above, we obtained the results which is shown in Table 11 . The results demonstrate that owing to $\mathrm{B} / \mathrm{C}$ being greater than 1 , from a social perspective this project is effective, and Net Present Value (NPV) was calculated as $70.5 \mathrm{RMB} / \mathrm{m}^{2}$.

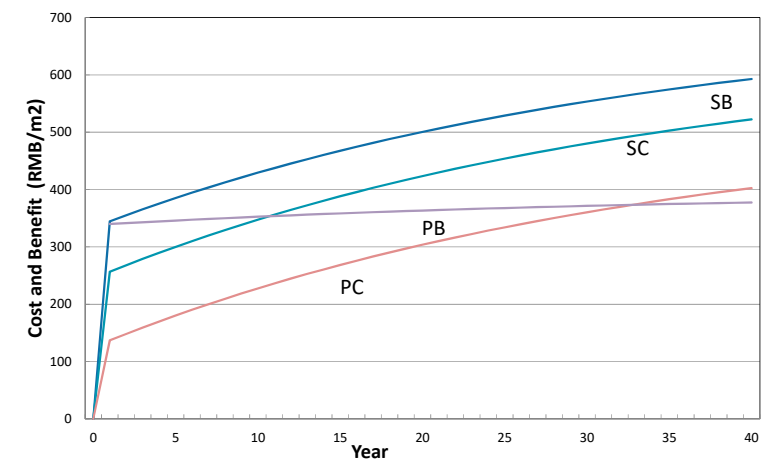

Figure 11. Comparison analysis results from two perspectives, private and social.

Table 11. Results of B/C and NPV.

\begin{tabular}{ccc}
\hline Item & $\mathbf{B} / \mathrm{C}$ & $\mathrm{NPV}$ \\
\hline Value & 1.13 & $70.5\left(\mathrm{RMB} / \mathrm{m}^{2}\right)$ \\
\hline
\end{tabular}




\section{Discussion}

Compared with previous work, this paper tried to calculate costs and benefits in a precise way. By using ArcGIS, study area was limited to a watershed and calculation was executed precisely. Results show that project is not effective from a private perspective; one of reasons was considered to be the high maintenance fee. However, the project was effective from a social perspective as reduction of social flood risk was included in benefits. Besides, the reason for selecting greater precipitation in 3.2 is that our benefit (reduction of flood risk) in cost-benefit analysis was based on the entire target area car loss (the worst situation); smaller precipitation cannot lead to the worst situation. Parameter-precipitation is included in the cost-benefit analysis frame; by increasing investment amount, the critical value of precipitation can be enlarged. This could be expected to help urban designers to estimate the sponge city area required by referring to local precipitation data.

Besides, as Zhang et al. mentioned in their paper, the usage of simplified hydrologic model and the two assumptions can lead to inundation simulating error in three ways: Firstly, CN should take different values based on each sub-catchment's condition, not a unified value in study area. (However, in $\mathrm{CN}$ value estimating of before/after sponge city, this error was mitigated (not so high) by building sponge city in the two final confluence spots; if sponge city is built on the upstream, the error rate will be very high because of the overestimate TR in upstream can lead to non-existing overflow running downstream). Secondly, unified design drainage capacity is not the drainage way in reality. It is not a constant value, it should be gradually increased to the design drainage capacity. Thirdly, the treatment of sewer conveyance as a permanent conveyable flow rate for storm events could overestimate sewer conveyance during certain periods of a storm event and underestimate conveyance when there is surcharge. In addition, ignoring the spatial distribution of drainage process and precipitation (both unevenly distributed) leads to error too. They can only be acceptable when the study area is small. If the precipitation is not distributed evenly, more precipitation stations are necessary to improve simulation accuracy, and different precipitation data should be used to calculate runoff of different sub-catchments.

\section{Conclusions}

Based on the analysis mentioned above, we have come to the conclusion that although sponge city was not effective from a private perspective, it was effective from a social perspective and unit benefit was calculated as $352 \mathrm{RMB} / \mathrm{m}^{2}$ and $366 \mathrm{RMB} / \mathrm{m}^{2}$ from private and social perspectives, respectively. Bianchini calculated a range of $76-670 \mathrm{RMB} / \mathrm{m}^{2}$ for private benefit and $31-717 \mathrm{RMB} / \mathrm{m}^{2}$ for social benefit and concluded that from both perspectives, private and social, target project was effective. Besides, study area was located in Nangang district, Harbin City, which is a cold area. In the next step, we expect to validate and improve this method in a warm place after collecting data. A GIS-based urban storm inundation method was used to simulate the inundation result. Through a set target depth, the sponge city can be effective to control flood risk; threshold precipitation value was obtained. Owing to the usage of GIS, the discretization of district (floodplain) was achieved, and the quantitative inundation depth reducing effect in small-scale area from sponge city (green roofs) could be calculated. The threshold precipitation is expected to help urban designers to have one more parameter to refer to, combined with local meteorological data, when making urban design plans, e.g., with meteorological data, designers can estimate minimum sponge city area necessary for controlling waterlogging or flood risk by using the method and then estimate the investment amount. Moreover, there are also some extreme situations, in which case if full target areas are built with sponge city and the waterlogging or inundation does not improve, other options such as a drainage system upgrading project may be the optimal measures for that city or district. This means sponge city has upper limit for the control of overflow ( $\mathrm{CN}$ has minimum value, and sr has maximum value; according to Equation (1b) and (1a), the surface runoff occurs when precipitation surpasses a critical value).

Owing to the hydrologic model being a simplified one, there are some limitations to the analysis method presented in this paper: (1) Many parameters were simplified, such as land use at different locations. This kind of simplification can cause simulation error. In order to improve the method 
application, model parameters' sensitivity calibration and more verification work should be done in the future. (2) Simulation of final inundation does not result in the physically-dynamic inundation process; it cannot help to optimize the sponge city building location (the technology used in this case study was Green Roofs; the inundation process maybe not so important; however, if other technology was used, such as rain garden technology, building a project not near to the large waterlogging sub-catchment but in a more stream confluent place could be better).

Author Contributions: Conceptualization, X.F.; methodology, X.F.; software, T.M.; validation, X.F.; formal analysis, X.F.; investigation, X.F.; resources, X.F.; data curation, X.F.; writing-original draft preparation, X.F.; writing-review and editing, T.M.; visualization, X.F.; supervision, T.M.; project administration, T.M.; funding acquisition, T.M.

Funding: This research received no external funding.

Acknowledgments: This study has been supported by Toru Matsumoto, The University of Kitakyushu. The authors also want to thank Guoyun Zhou, Nishinippon Institute of Technology and Shanghong Zhang, North China Electric Power University and Yong Liu, Henan University.

Conflicts of Interest: The authors declare no conflict of interest.

\section{References}

1. Baidu. 2012 Beijing Rainstorm. Available online: https://baike.baidu.com/item/7\%C2\%B721\%E5\%8C\% 97\%E4\%BA\%AC\%E7\%89\%B9\%E5\%A4\%A7\%E6\%9A\%B4\%E9\%9B\%A8\#reference-[15]-9014935-wrap \T1 textgreater \{\} (accessed on 19 February 2019).

2. Wang, H.; Mei, C.; Liu, J.; Shao, W. A new strategy for integrated uban water management in China: Sponge City. J. Tech. Sci. 2018, 61, 317-329.

3. Fletcher, T.D.; Shuster, W.; Hunt, W.F.; Ashley, R.; Butler, D.; Arthur, S.; Trowsdale, S.; Barraud, S.; Semádeni-Davies, A.; Bertrand-Krajewski, J.-L.; et al. SUDS, LID, BMPs, WSUD and more-The evolution and application of terminology surrounding urban drainage. Urban Water J. 2014, 12, 525-542. [CrossRef]

4. Shao, W.; Liu, J.; Yang, Z.; Yang, Z.; Yu, Y.; Li, W. Carbon Reduction Effects of Sponge City Construction: A Case Study of the City of Xiamen. J. Energy Procedia 2018, 152, 1145-1151. [CrossRef]

5. Lin, X.; Ren, J.; Xu, J.; Zheng, T.; Cheng, W.; Qiao, J.; Huang, J.; Li, G. Pridiction of life cycle carbon emissions of Sponge city projects: A case study in Shanghai, China. Sustainability 2018, 10, 3978. [CrossRef]

6. Mentens, J.; Raes, D.; Hermy, M. Green roofs as a tool for solving the rainwater runoff problem in the urbanized 21st century? Landsc. Urban Plan. 2006, 77, 217-226. [CrossRef]

7. Elizabeth, E.; Simcock, R.; Fassman-Beck, E. Moisture Measurements as Performance Criteria for Extensive Living Roof Substrates. J. Environ. Eng. 2012, 138, 841-851.

8. Zhang, B.; Xie, G.; Zhang, C.; Zhang, J. The economic benefits of rainwater-runoff reduction by urban green spaces: A case study in Beijing, China. J. Environ. Manag. 2012, 100, 65-71. [CrossRef] [PubMed]

9. Carter, T.; Keeler, A. Life-cycle cost-benefit analysis of extensive vegetated roof systems. J. Environ. Manag. 2008, 87, 350-363. [CrossRef] [PubMed]

10. Bianchini, F; Hewage, K. Probabilistic Social Cost-benefits analysis for Green Roofs: A lifecycle Approach. J. Build. Environ. 2012, 58, 152-162. [CrossRef]

11. Gironás, J.; Roesner, L.A.; Rossman, L.A.; Davisd, J. A new applications manual for the Storm Water Management Model (SWMM). J. Environ. Model. Softw. 2010, 25, 813-814.

12. Neal, J.; Dunne, T.; Sampson, C.; Smith, A.; Bates, P. Optimisation of the two-dimensional hydraulic model LISFOOD-FP for CPU architecture. J. Environ. Model. Softw. 2018, 107, 148-157. [CrossRef]

13. Schumann, G.J.-P.; Neal, J.C.; Mason, D.C.; Bates, P.D. The accuracy of sequential aerial photography and SAR data for observing urban flood dynamics, a case study of the UK summer 2007 floods. Remote Sens. Environ. 2011, 115, 2536-2546. [CrossRef]

14. Zhang, S.; Pan, B. An urban storm-inundation simulation method based on GIS. J. Hydrol. 2014, 517, 260-268. [CrossRef]

15. Monterusso, M.; Rowe, D.; Rugh, C.; Russell, D. Runoff Water Quantity and Quality from Green Roof Systems. Acta Hortic. 2004, 369-376. [CrossRef] 
16. De Moel, H.; Aerts, J.C.J.H. Effect of uncertainty in land use, damage models and inundation depth on flood damage estimates. J. Natural Hazards 2010, 58, 407-425. [CrossRef]

17. Clark, C.; Adriaens, P.; Talbot, F.B. Green roof valuation: A probabilistic economic analysis of environmental benefits. J. Environ. Sci. Technol. 2008, 42, 2155-2161. [CrossRef]

18. Mccuen, R.H. A Guide to Hydrologic Analysis Using SCS Method; Prentice Hall Inc.: Englewood Cliffs, NJ, USA, 1982; pp. 67-97.

19. Mark, O.; Apirumanekul, C.; Kamal, M.M.; Praydal, G. Modelling of Urban Flooding in Dhaka City. In Proceedings of the World Water and Environmental Resources Congress 2001, Orlando, FL, USA, 20-24 May 2001; pp. 333-343.

20. Arrighi, C.; Pregnolato, M.; Dawson, R.J.; Castelli, F. Preparedness against mobility disruption by floods. J. Sci. Total Environ. 2019, 654, 1010-1022. [CrossRef]

21. Japan Automobile Federation. Available online: http://www.jaf.or.jp/eco-safety/safety/usertest/submerge/ detail1.htm (accessed on 19 February 2019).

22. Zhang, M.; Chi, X. The Analysis of Present Condition Investigation and Development Counterplan in Harbin Municipal Sewerage system. J. Environ. Sci. Manag. 2010, 35, 20-21. (In Chinese)

23. Bid Winning Announcement of Qunli Healthy Ecological Garden. Available online: http://www.ccgp.gov.cn/ cggg/dfgg/zbgg/201601/t20160108_6439674.htm (accessed on 19 February 2019).

24. Wan, J. Study on the present conditions and the Corresponding Strategy for the Development of Green roof in Shanghai. J. Chin. Urban For. 2009, 7, 16-19. (In Chinese)

25. Beijing Institute of landscape. Available online: https://wenku.baidu.com/view/9d7e4d2e25c52cc58bd6be4e. html (accessed on 19 February 2019).

26. Willis, K.G.; Garrod, G.; Scarpa, R.; Powe, N. The Social and Environmental Benefits of Forests in Great Britain, Report to the Forestry Commission; Centre for Research in Environmental Appraisal and Management, University of Newcastle: Newcastle upon Tyne, UK, 2003; p. 13.

27. Shi, Y.; Zhang, D.; Xu, Y.; Zhou, B. Changes of heating and cooling degree days over China in response to global warming of $1.5^{\circ} \mathrm{C}, 2^{\circ} \mathrm{C}, 3^{\circ} \mathrm{C}$ and $4{ }^{\circ} \mathrm{C}$. Adv. Clim. Chang. Res. 2018, 9, 192-200. [CrossRef]

28. Lee, A.; Sailor, D.; Larson, T.; Ogle, R. Developing a web-based tool for assessing green roofs. In Proceedings of the Greening Rooftops for Sustainable Communities, Minneapolis, MN, USA, 29 April-1 May 2007.

29. Ye, J.; Xiao, H.; Xu, W.; Li, H. Research on rainwater retention from Green Roofs. J. Water Waste. Eng. 2006, 5, 139-143. (In Chinese)

30. Yang, J.; Yu, Q.; Gong, P. Quantifying air pollution removal by green roofs in Chicago. J. Atmosph. Environ. 2008, 42, 7266-7273. [CrossRef]

31. Blackhurst, M.; Hendrickson, C.; Matthews, H.S. Cost-Effectiveness of Green Roofs. J. Archit. Engin. 2010, 16, 136-143. [CrossRef]

32. Jamasb, T.; Nepal, R. Issues and options in waste management: A social cost-benefit analysis of waste-to-energy in the UK. J. Res. Conser. Recy. 2010, 54, 1341-1352. [CrossRef]

33. Wang, J.; Wu, H.; Tam, V.W.Y.; Zuo, J. Considering life-cycle environmental impacts and society's willingness for optimizing construction and demolition waste management fee: An empirical study of China. J. Clean. Prod. 2019, 206, 1004-1014. [CrossRef]

34. Currie, B.A.; Bass, B. Estimate of air pollution mitigation with green plants and green roofs using the UFORE model. In Proceedings of the Third Annual Greening Rooftops for Sustainable Communities Conference, Awards and Trade Show, Washington, DC, USA, 4-6 May 2005.

35. Baidu. Vehicle Wading Insurance. Available online: https://baike.baidu.com/item/\%E6\%B6\%89\%E6\%B0\% B4\%E9\%99\%A9/1739708?fr=aladdin (accessed on 19 February 2019). 
36. GonzálezDávila, M.; Stithou, G.; Pescaroli, L.; Pietrantoni, P.; Koundouri, P.; Díaz-Simal, B.; Rulleau, N.; Touili, F.; Hissel, E. Penning-Rowsell: Promoting resilient economies by exploring insurance potential for facing coastal flooding and erosion: Evidence from Italy, Spain, France and United Kingdom. J. Coast. Eng. 2014, 87, 183-192.

37. Spekkers, M.H.; Kok, M.; Clemens, F.H.L.R.; Ten Veldhuis, J.A.E. A statistical analysis of insurance damage claims related to rainfall extremes. J. Hydrol. Earth Syst. Sci. 2013, 17, 913-922. [CrossRef] 